\title{
Simulation of an application of the Hartz-IV reform in Austria
}

\author{
MICHAEL FUCHS, Mag.rer.soc.oec.* \\ KATARINA HOLLAN, Mag.rer.soc.oec.* \\ KATRIN GASIOR, Mag.rer.soc.oec.*
}

Preliminary communication**

JEL: D31, H53, I32, I38

doi: $10.3326 /$ pse. 41.4 .4

\begin{abstract}
* The work described in this paper has been funded by the Austrian Federal Ministry of Finance. The results are based on the tax-/benefit microsimulation models EUROMOD (version G4.0+) and SORESI (version 2017.01). EUROMOD is maintained, developed and managed by the Institute for Social and Economic Research (ISER) at the University of Essex, in collaboration with national teams from the EU member states. The process of extending and updating EUROMOD is financially supported by the Directorate General for Employment, Social Affairs and Inclusion of the European Commission [Progress grant no. VS/2011/0445]. SORESI is an online simulation tool for Austria based on EUROMOD. Its development was based on a cooperative venture between the Austrian Federal Ministry of Labour, Social Affairs and Consumer Protection and the following project partners (in alphabetical order): European Centre for Social Welfare Policy and Research, Austria; Federal Computing Centre (Bundesrechenzentrum), Austria; ISER; Katholieke Universiteit Leuven, Belgium; makingChoices.be; Statistics Austria. Compared to EUROMOD, SORESI makes more extended use of the underlying microdata instead of simulating specific income components. The calculations in this paper are based on microdata derived using the EU Statistics on Incomes and Living Conditions (EU-SILC) for Austria 2015 made available by Statistics Austria.

This paper was presented at the conference Social Protection Policies and Microsimulation Workshop hosted by the Institute of Public Finance in Zagreb, 12-13 June 2017. The authors would like to thank to two anonymous referees for their valuable comments and suggestions.

${ }^{* *}$ Received: June 30, 2017
\end{abstract}

Accepted: September 13, 2017

\section{Michael FUCHS}

European Centre for Social Welfare Policy and Research, Berggasse 17, 1090 Wien, Austria e-mail: fuchs@euro.centre.org

ORCiD: 0000-0002-3957-8104

\section{Katarina HOLLAN}

European Centre for Social Welfare Policy and Research, Berggasse 17, 1090 Wien, Austria

e-mail: hollan@euro.centre.org

ORCiD: 0000-0001-8725-0253

\section{Katrin GASIOR}

Institute for Social and Economic Research, University of Essex, Wivenhoe Park, Colchester, CO4 3SQ, United Kingdom

e-mail: k.gasior@essex.ac.uk

ORCiD: 0000-0003-4342-1174 


\section{Abstract}

This paper examines the application of the German Hartz-IV model in Austria. If the Hartz-IV reform were to be transferred to Austria, this would imply that instead of unemployment assistance (Notstandshilfe), the social-assistance-type minimum income benefit (Bedarfsorientierte Mindestsicherung) would be follow-up assistance after unemployment benefit expires. The analysis is carried out using the tax-benefit microsimulation models EUROMOD and SORESI based on the latest EU-SILC 2015 data for Austria. We simulate a baseline scenario according to the minimum income benefit regulations of the nine federal states for the year 2017 and a scenario including a proxy for an asset check of capital income. In addition, following current political discussions and developments, we simulate a ceiling scenario, in which the sum of minimum standards per household is capped at EUR 1,500 per month. The direct (monetary) effects of the potential reform are analysed on three levels: fiscal implications; number of receiving households including socio-demographic characteristics; income distribution and risk of poverty.

Keywords: social assistance, public expenditure, household income, Austria, microsimulation

\section{INTRODUCTION}

The report by the commission Modern Services on the Labour Market (chaired by Peter Hartz) from 2002 contains recommendations for reforms in labour market policy and placement service in Germany. At the same time, measures were developed to increase the incentives for job search for the (long-term) unemployed. The resulting legal regulations were implemented in 2003 (Hartz I and II), 2004 (Hartz III) and 2005 (Hartz IV).

Basically, Hartz IV combines the hitherto existing unemployment assistance (Arbeitslosenhilfe) and social assistance for persons capable of gainful employment into unemployment benefit II (Arbeitslosengeld II), a new basic security provision for jobseekers. Compared to the former unemployment assistance, a change from standard of living to basic security took place: the benefit amount is now based on a lump-sum assessment of needs and is independent of income from previous employment. Unemployment benefit II (like the previous unemployment assistance) is paid once the entitlement to the insurance-based unemployment benefit (I) has expired. The latter was left more or less unchanged after the reform.

Since its introduction in Germany, a transfer of the Hartz-IV reform has been a recurring topic of public and political debate in Austria. If the reform were to be transferred, this would imply that after the expiration of unemployment benefit (Arbeitslosengeld), instead of unemployment assistance (Notstandshilfe), a minimum income benefit (Bedarfsorientierte Mindestsicherung) would be the follow-up benefit. As was the case in Germany, unemployment assistance represents a meanstested insurance benefit, whereas minimum income benefit is a social-assistancetype benefit. 
Some representatives from Austrian institutions like the Federal Ministry of Finances or the Chamber of Commerce argue that a regulation similar to Hartz IV would reduce social expenditure and contribute to unemployment reduction by increasing incentives for taking up employment, especially for the long-term unemployed (cf. e.g. Schmidt, 2016:2), while some other representatives from institutions like the Federal Ministry for Social Affairs and the Chamber of Labour point to the negative outcomes of the reform in terms of increased risk of poverty and the expansion of the low-pay sector as has happened in Germany (AK Wien, 2016).

Given the controversial political debate, the European Centre Vienna was contracted by the Federal Austrian Ministry of Finance to analyse the direct monetary effects of a corresponding application of the German model to Austria by using tax-/benefit microsimulation models (EUROMOD and SORESI) based on the latest EU-SILC 2015 micro-data from Statistics Austria. The present paper describes the main findings from this analysis.

The direct (monetary) effects of the replacement of unemployment assistance by minimum income benefit are analysed on three levels:

- fiscal implications;

- number of beneficiaries/receiving households, including socio-demographic characteristics;

- income distribution and risk of poverty.

Current political discussions and developments in Austria are tending towards capping the sum of minimum standards within minimum income benefit with a maximum amount per household regardless of its size. This results in the following simulation scenarios:

- Scenario 1: basic scenario according to the minimum income benefit regulations of the nine federal states for the year 2017;

- Scenario 2: basic scenario including a proxy for an asset check of capital income, which is specified in the respective laws;

- Scenario 3: basic scenario with a cap on the sum of minimum standards at EUR 1,500 per month and household including a proxy for an asset check of capital income.

\section{SYSTEMATIC FRAMEWORK}

Given that the qualifying period is fulfilled, the insurance-based unemployment benefit I (Arbeitslosengeld I) in Germany provides a replacement rate of 60 to $67 \%$ of the previously earned income from work. The potential receiving period is three to 24 months (usually twelve months, older people 15-24 months). After expiration of unemployment benefit I, the social-assistance-type unemployment benefit II (Arbeitslosengeld II) is granted. It is composed of flat-rate amounts for subsistence plus housing support (where appropriate) (AK Wien, 2016; BockSchappelwein et al., 2014; Bräuninger, Michaelis and Sode, 2013). 
In the Austrian system, unemployment benefit is also granted if the unemployed person has fulfilled the qualifying period. Again, the amount depends on the previously earned income (replacement rate of $55 \%$ with possible supplementary amounts). The potential receiving period is dependent on age and insurance history and ranges between 20 and 52 weeks (basically: 20-30 weeks; older people: 39-52 weeks; after vocational rehabilitation up to 78 weeks).

Unemployment assistance is a means-tested insurance benefit, since the income of the spouse is taken into account. The basis for the calculation is also the previous income from work (92 or $95 \%$ of unemployment benefit). For the means-test of the income of the spouse, there are amounts of exemption, which are doubled or tripled for persons that become unemployed from the age of 50. Unemployment assistance is generally granted for a period of 52 weeks but may be annually reapplied for.

As in the case of unemployment benefit II in Germany, the previous income from work is not relevant for the calculation of the tax-financed minimum income benefit. There are uniform needs-based standard rates (in 2017 usually EUR 844.46 per month for single persons and single parents including a $25 \%$ basic amount for housing needs). In contrast to unemployment assistance, for eligibility for minimum income benefit, a household's own assets that exceed a certain amount of exemption are also relevant.

When unemployment assistance is received there is the possibility of marginal earnings (2017 up to EUR 425.70 per month). For the minimum income benefit, there are certain amounts of exemptions for employment income: in most of the federal states, an amount of $15 \%$ of the monthly net income is granted for a period of 18 months after a period of at least six months of minimum income benefit claim, with a lower limit of $7 \%$ and a ceiling of $17 \%$ of the standard rate for single persons. In Lower Austria and Upper Austria an employment entry bonus of up to one third of the monthly net income has recently been introduced (AK, 2017).

Since the minimum income benefit may also be obtained as a supplement to (low) other incomes, households with unemployment assistance beneficiaries with correspondingly low previous household incomes have already been able to apply for it. In 2015 (providing the latest available figures), the average number of people receiving unemployment assistance per month amounted to 163,040 or $1.9 \%$ of the Austrian population. Among these there were, on average, 30,218 recipients $(18.5 \%)$ whose household was additionally receiving minimum income benefit. The latter group would be little affected by a potential reform (AK Wien, 2016).

\section{DATA AND METHODS}

The analysis is carried out using the tax-/benefit microsimulation models EUROMOD and SORESI for the policy year 2017 based on the latest EU-SILC 2015 data (with incomes for 2014) for Austria with additional disaggregated 
income variables provided by Statistics Austria. The data was uprated to 2017 with the use of empirical indicators.

EUROMOD is a tax-/benefit microsimulation model for the European Union, based on household micro-data from representative sources (mostly EU-SILC) and calculates disposable income for each household in the dataset (Sutherland and Figari, 2013). This calculation is made up of elements of income taken from the survey data (e.g. employee earnings) combined with components that are simulated by the model (taxes and benefits).

SORESI is an online tax-/benefit microsimulation tool for Austria based on EUROMOD (Fuchs and Gasior, 2014). It is further adapted to the effective outcomes of the Austrian tax-/benefit system by additional income information being taken directly from the data for policies that are difficult to simulate due to missing information related to individual social insurance histories (e.g. in the case of unemployment benefits). However, as there have been significant policy changes since 2014, for this paper, apart from minimum income benefit, we also simulate social (insurance) contributions, income tax and family allowances.

The basic output from EUROMOD and SORESI is the micro-level change in household disposable income as a result of simulated reforms (in the concrete case: policy system with unemployment assistance vs. policy system with minimum income benefit instead). The data output of EUROMOD and SORESI was analysed using the statistics programs Stata and SPSS.

The sample for the simulation of minimum income benefit contains all households in EU-SILC with at least one household member that is an unemployment assistance beneficiary, who has received the benefit for at least one month. ${ }^{1}$ Unemployment assistance is set to zero. Subsequently, minimum income benefit is simulated instead, according to the specific regulations in the nine federal states and the composition and socio-demographic characteristics of the affected households. It is assumed that the regulations for unemployment benefit (for example, receiving period, qualifying period) remain unchanged from the EU-SILC data collection 2015.

Within the simulation of minimum income benefit both means of subsistence and potential housing needs are simulated. For the latter, the basic amount for housing needs (included in the standard rates and usually 25\% thereof) and potentially received housing allowances outside minimum income benefit are also taken into account. Incomes to be included in the means-test (implemented according to the nine federal state regulations) as well as actual housing costs are also taken from

\footnotetext{
${ }^{1}$ Unweighted, the persons/households with unemployment assistance relevant for the analysis are as follows:

- households with unemployment assistance recipients: 361 ;

- unemployment assistance recipients: 381;

- members in unemployment-assistance households: 895 .
} 
the EU-SILC data and are offset with potential benefit amounts (see appendix for more details).

First, a basic scenario (S1) corresponding to the regulations for minimum income benefit in the nine federal states for the year 2017 is simulated. ${ }^{2}$ Own assets are also relevant for minimum income benefit. As there is no corresponding information in the EU-SILC data, a proxy is applied in the basic scenario with an asset test (S2): test for capital income according to EU-SILC data, which, assuming a net interest rate of $1 \%$, exceeds the amounts of exemption on assets (in 2017 in most federal states EUR 4,222.30 per household). ${ }^{3}$

Current political discussions and developments related to minimum income benefit aim to cap minimum standards with a maximum amount per household regardless of its size. The upper limit also includes any supplementary housing need. In the federal state Lower Austria the sum of the minimum standards within a household is limited to EUR 1,500 per month. Even if other income is earned and this is topped up by minimum income benefit, the latter is only granted as long as the total net household income does not exceed EUR 1,500. ${ }^{4}$ Therefore, in Scenario 3 (S3) the sum of minimum standards (=total net household income) is capped at EUR 1,500 per month/household ${ }^{5}$ (plus including a proxy for an asset check of capital income as in S2).

We simulate only the first-round effect (without accounting for behavioural changes) and the direct outcomes related to fiscal costs and disposable household income of the reform. Indirect consequences such as, e.g. future lower pension entitlements, are not considered. Likewise, additional costs for society (e.g. regarding health, social participation) arising from an increased risk of poverty (cf. e.g. Lamei et al., 2017) are not taken into account.

\footnotetext{
${ }^{2}$ However, in all federal states without ceiling for minimum standards, in order to make the differences with respect to Scenario 3 more visible.

${ }^{3}$ The difference in estimated values for gross household incomes between national accounts and EU-SILC decreases from 10.8 to $3.6 \%$ if incomes from assets are not taken into account. This fact points to the underrecording of incomes from assets in EU-SILC (Statistik Austria, 2016:51). Thus, the share of households passing the means-test for minimum income benefit in terms of capital income might be over-estimated, although we assume a relatively high interest rate for capital income. However, exclusion from entitlement to minimum income benefit in the case of home ownership (not reported here) showed similar results to the test for capital income.

${ }^{4}$ In the federal state of Burgenland for example, also in which a ceiling was also introduced, the amount of the minimum income benefit (and not the total household income) is capped at EUR 1,500 per month. As this regulation shows only a minor additional impact compared to the basic scenario, it is not reported here. ${ }^{5}$ The legal explanations justify the monthly ceiling of EUR 1,500 by arguing that the benefit income should not lead to a higher household income than one that would be received from an average employment income. For a household with minimum income benefit as single income source located in Vienna, the ceiling of EUR 1,500 per month would roughly correspond to the minimum standards (incl. basic amount for housing, excl. additional housing allowance) of a couple plus one child.
} 


\subsection{STATUS QUO UNEMPLOYMENT ASSISTANCE:}

EXPENDITURE AND BENEFICIARIES (-HOUSEHOLDS)

According to EU-SILC data (uprated to 2017), the following statistics are obtained for persons/households who have received unemployment assistance for at least one month in the reporting year:

- 277,000 households (7.3\% of all households in EU-SILC) with 296,000 beneficiaries and 736,000 household members $(3.5 \% / 8.7 \%$ of all persons in EU-SILC);

- the average receiving duration (within the reporting year) is 6.6 months;

- expenditure for unemployment assistance amounts to 1,454 million EUR ( $0.42 \%$ of GDP 2016 and $1.45 \%$ of total social expenditure 2015 );

- out of the 277,000 households, 56,000 households $(20.2 \%)$ receive additional benefits to prevent social exclusion (minimum income benefit and/or social assistance), the expenditure amounts to 338 million EUR $(0.1 \%$ of GDP 2016 and $0.34 \%$ of total social expenditure 2015);

- in total, the 277,000 households receive 1,792 million EUR of unemployment assistance and benefitsaimedat preventing social exclusion $(0.51 \%$ of GDP 2016 and $1.79 \%$ of total social expenditure 2015).

Men account for $59 \%$ of unemployment assistance recipients whereas they receive $65 \%$ of expenditure, having on average higher average amounts than women. In unemployment-assistance households, $40 \%$ of the members are men, $37 \%$ are women and $23 \%$ are children (see table 1 ). ${ }^{6}$

\section{TABLE 1}

Unemployment assistance: recipients, members in households and total expenditure by women and men (and children)

\begin{tabular}{|c|c|c|c|c|c|c|}
\hline \multirow[t]{2}{*}{$\begin{array}{l}\text { Gender/ } \\
\text { children }\end{array}$} & \multicolumn{2}{|c|}{$\begin{array}{c}\text { Unemployment } \\
\text { assistance recipients }\end{array}$} & \multicolumn{2}{|c|}{$\begin{array}{c}\text { Members in } \\
\text { unemployment- } \\
\text { assistance households }\end{array}$} & \multicolumn{2}{|c|}{$\begin{array}{l}\text { Expenditures (related } \\
\text { to unemployment } \\
\text { assistance recipients) }\end{array}$} \\
\hline & in 1,000 & in $\%$ & in $\mathbf{1 , 0 0 0}$ & in \% & in million $€$ & in $\%$ \\
\hline Women & 122 & 41.0 & 270 & 36.6 & 503 & 34.6 \\
\hline Men & 175 & 59.0 & 296 & 40.2 & 951 & 65.4 \\
\hline Children & - & - & 171 & 23.2 & - & - \\
\hline Total & 296 & 100.0 & 736 & 100.0 & 1,454 & 100.0 \\
\hline
\end{tabular}

Source: Own analysis EU-SILC 2015 (uprated to 2017).

Related to household type, by far the largest share of unemployment assistance both according to number of households and according to expenditure, of about one third, is accounted for by single persons, followed by couples without children (18 to $19 \%$; see table 2).

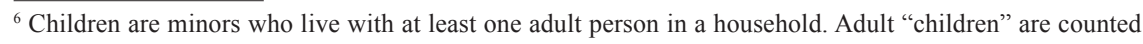
as women or men. 
TABLE 2

Unemployment assistance: receiving households and total expenditure by household type

\section{Household type}

\begin{tabular}{|c|c|c|c|c|}
\hline & in 1,000 & in $\%$ & in million $€$ & in $\%$ \\
\hline Single persons & 93 & 33.5 & 518 & 35.6 \\
\hline Couple without children & 49 & 17.6 & 275 & 18.9 \\
\hline Other households w/o children* & 31 & 11.2 & 131 & 9.0 \\
\hline Single parents & 19 & 6.9 & 94 & 6.5 \\
\hline Couple, $1-2$ children & 39 & 14.0 & 179 & 12.3 \\
\hline Couple, $3+$ children & 16 & 5.9 & 102 & 7.0 \\
\hline Further households w children** & 30 & 10.9 & 155 & 10.6 \\
\hline Total & 277 & 100.0 & 1,454 & 100.0 \\
\hline
\end{tabular}

Source: Own analysis EU-SILC 2015 (uprated to 2017).

In the unemployment-assistance households, approximately three quarter of the households receive (additional) income from work in the reporting year. The same is true with respect to (other) unemployment benefits. These are followed by benefits for sickness and care (56\%), family benefits (46\%) and capital income (42\%). Benefits to prevent social exclusion, pensions (incl. for work accidents) as well as housing allowances (outside benefits to prevent social exclusion) are drawn in about one fifth of the households each. $15 \%$ of households also receive maintenance benefits as income. In turn, maintenance payments are provided by $12 \%$ of the affected households (see table 3).

\section{TABLE 3}

Unemployment-assistance households: (additional) income types and paid maintenance

Income types/ paid maintenance

Households

\begin{tabular}{|c|c|c|}
\hline & absolute in 1,000 & in $\%$ of all 277,000 \\
\hline Income from work & 212 & 76.4 \\
\hline (Other) unemployment benefits & 207 & 74.7 \\
\hline Sickness, care benefits & 155 & 56.0 \\
\hline Family benefits & 128 & 46.0 \\
\hline Capital income & 117 & 42.2 \\
\hline Benefits to prevent social exclusion & 56 & 20.2 \\
\hline Pensions (incl. for work accidents) & 56 & 20.2 \\
\hline Housing benefits & 53 & 19.1 \\
\hline Maintenance benefits & 40 & 14.6 \\
\hline Income of children $<16$ years & 12 & 4.3 \\
\hline Education benefits & 10 & 3.8 \\
\hline Maintenance payments & 33 & 11.8 \\
\hline
\end{tabular}

Source: Own analysis EU-SILC 2015 (uprated to 2017). 
The results for all households, for which we alternatively simulate minimum income benefit for at least one month instead of unemployment assistance, are presented below. Since the results for the three scenarios go in a similar direction as regards the duration of benefit receipt and socio-demographic characteristics, corresponding results are only shown for the basic scenario without asset check (S1). ${ }^{7}$

In the basic scenario without asset check (S1), minimum income benefit is simulated for 158,000 households ( $57 \%$ of original 277,000 ) with 348,000 members ( $47 \%$ of the original 736,000$)$. The average duration of the simulated minimum income benefit receipt during the reporting year increases by 0.6 months to 7.2 months. ${ }^{8}$ The simulated expenditure for minimum income benefit amounts to EUR 781 million (54\% of the originally EUR 1,454 million for unemployment assistance).

The proxy for the asset check (S2) further reduces the number of simulated recipient households to $131,000(47 \%)$ and the sum of the simulated expenditures to EUR 670 million (46\%).

Significant additional reductions in expenditure result from the capping scenario (S3), ${ }^{9}$ in which case reductions also affect the benefits preventing social exclusion from the data (for more details see appendix): only 93,000 households (34\%) receive simulated minimum income benefit, simulated expenditure amounts to EUR 450 million (31\%). Benefits preventing social exclusion from the EU-SILC data would still be received by 42,000 households ( $75 \%$ of the originally 56,000 ), with an expenditure of EUR 240 million (71\% of the originally EUR 338 million). Together, the simulated minimum income benefits and/or the benefits preventing social exclusion are drawn by 108,000 former unemployment-assistance households (39\%); the total expenditure amounts to EUR 690 million (39\% of the original EUR 1,792 million for unemployment assistance and benefits against social exclusion) in the reporting year (see table 4).

However, in all simulated scenarios, because of the abolishment of unemployment assistance there is a reduction in income tax revenue of about EUR 30 million. ${ }^{10}$

\footnotetext{
${ }^{7}$ Results for other scenarios are available upon request.

${ }^{8}$ At the level of the individual household, the number of simulated minimum income benefit months corresponds to the number of original unemployment assistance months, since minimum income benefit can only be received alternatively for these months.

${ }^{9}$ In $54 \%$ of those 153,000 unemployment-assistance households, which in the basic scenario with asset check (S2) receive simulated minimum income benefit and/or benefits against social exclusion from the SILC data, the average monthly total net household income is above the ceiling of EUR 1,500.

${ }^{10}$ Unemployment assistance represents a non-taxable income but is taken into account for the determination of the average tax rate for taxable income.
} 


\section{TABLE 4}

Status quo (unemployment assistance) and simulated minimum income benefitscenarios: number of households and expenditure

\begin{tabular}{|c|c|c|}
\hline Scenario & $\begin{array}{l}\text { Households } \\
\text { in } \mathbf{1 , 0 0 0} \\
\end{array}$ & $\begin{array}{l}\text { Expenditure in } \\
\text { million EUR }\end{array}$ \\
\hline \multicolumn{3}{|l|}{ Status quo } \\
\hline Unemployment assistance (UA) & 277 & 1,454 \\
\hline Benefits against social exclusion/data & 56 & 338 \\
\hline Total & 277 & 1,792 \\
\hline \multicolumn{3}{|l|}{ Scenario 1: Base without asset check } \\
\hline Minimum income benefit (MIB) simulated & 158 & 781 \\
\hline Benefits against social exclusion/data & 56 & 338 \\
\hline $\begin{array}{l}\text { MIB simulated plus social exclusion/data } \\
\text { (=MIB total) }\end{array}$ & 179 & 1,119 \\
\hline $\begin{array}{l}\text { Difference unemployment assistance minus } \\
\text { MIB simulated }\end{array}$ & $-119(-43 \%)$ & $-673(-46 \%)$ \\
\hline $\begin{array}{l}\text { Difference UA + social exclusion/data minus } \\
\text { MIB total }\end{array}$ & $-98(-35 \%)$ & $-673(-38 \%)$ \\
\hline \multicolumn{3}{|l|}{ Scenario 2: Base with asset check capital income } \\
\hline Minimum income benefit simulated & 131 & 670 \\
\hline Benefits preventing social exclusion/data & 56 & 338 \\
\hline $\begin{array}{l}\text { MIB simulated plus social exclusion/data } \\
\text { (=MIB total) }\end{array}$ & 153 & 1,008 \\
\hline $\begin{array}{l}\text { Difference unemployment assistance minus } \\
\text { MIB simulated }\end{array}$ & $-146(-53 \%)$ & $-784(-54 \%)$ \\
\hline $\begin{array}{l}\text { Difference UA + social exclusion/data minus } \\
\text { MIB total }\end{array}$ & $-124(-45 \%)$ & $-784(-44 \%)$ \\
\hline \multicolumn{3}{|l|}{$\begin{array}{l}\text { Scenario 3: Ceiling 1,500 with asset check } \\
\text { capital income }\end{array}$} \\
\hline Minimum income benefit simulated & 93 & 450 \\
\hline Benefits preventing social exclusion/data & 42 & 240 \\
\hline $\begin{array}{l}\text { MIB simulated plus social exclusion/data } \\
\text { (=MIB total) }\end{array}$ & 108 & 690 \\
\hline $\begin{array}{l}\text { Difference unemployment assistance minus } \\
\text { MIB simulated }\end{array}$ & $-184(-66 \%)$ & $-1,004(-69 \%)$ \\
\hline $\begin{array}{l}\text { Difference UA + social exclusion/data minus } \\
\text { MIB total }\end{array}$ & $-169(-61 \%)$ & $-1,102(-61 \%)$ \\
\hline
\end{tabular}

Source: Own analysis with EUROMOD and SORESI.

For the analysis of sociodemographic characteristics, it shows that related to the original main recipients of unemployment assistance, ${ }^{11}$ there is a higher proportion of men among recipients and that expenditure on them is proportionally higher (plus 5.5/3.0 percentage points) for the simulated minimum income benefit entitlement.

The proportion of children has risen by 5.5 percentage points compared to unemployment assistance when looking at household members (see tables 1 and 5).

\footnotetext{
${ }^{11}$ If there is more than one unemployment-assistance recipient per household, the person with the higher number of receiving months was defined as the main beneficiary.
} 
Simulated minimum income benefit (S1): recipients, household members and expenditure by women, men (and children)

\begin{tabular}{|c|c|c|c|c|c|c|}
\hline \multirow[t]{2}{*}{$\begin{array}{l}\text { Gender, } \\
\text { children }\end{array}$} & \multicolumn{2}{|c|}{$\begin{array}{c}\text { Original unemployment } \\
\text { assistance main } \\
\text { recipients }\end{array}$} & \multicolumn{2}{|c|}{$\begin{array}{l}\text { Members in simulated } \\
\text { minimum income } \\
\text { benefit-households }\end{array}$} & \multicolumn{2}{|c|}{$\begin{array}{l}\text { Expenditure (related to } \\
\text { original unemployment } \\
\text { assistance main recipients) }\end{array}$} \\
\hline & in 1,000 & in $\%$ & in $\mathbf{1 , 0 0 0}$ & in \% & in million $€$ & in $\%$ \\
\hline Women & 56 & 35.5 & 114 & 32.6 & 247 & 31.6 \\
\hline Men & 102 & 64.5 & 134 & 38.6 & 534 & 68.4 \\
\hline Children & - & - & 100 & 28.7 & - & - \\
\hline Total & 158 & 100.0 & 348 & 100.0 & 781 & 100.0 \\
\hline
\end{tabular}

Source: Own analysis with EUROMOD and SORESI.

According to household type, simulated minimum income benefit compared to unemployment assistance for both number of households and expenditure shows a significantly higher proportion for single persons (plus 16.4/9.0 percentage points) and single parents (plus 2.7/3.7 percentage points). By trend these are household types with a smaller number of household members, in which there are no or only few possibilities of income provision by other persons than by the unemployment assistance recipient him/herself (see tables 2 and 6).

\section{TABLE 6}

Simulated minimum income benefit (S1): households (hh) and expenditure by household type

\begin{tabular}{|c|c|c|c|c|}
\hline \multirow[t]{2}{*}{ Household type } & \multicolumn{2}{|c|}{ Households } & \multicolumn{2}{|c|}{ Expenditure } \\
\hline & in 1,000 & in $\%$ & in million $€$ & in $\%$ \\
\hline Single persons & 79 & 49.9 & 348 & 44.6 \\
\hline Couple without children & 21 & 13.6 & 139 & 17.8 \\
\hline Other hh w/o children & 2 & 1.4 & 20 & 2.6 \\
\hline Single parents & 15 & 9.6 & 80 & 10.2 \\
\hline Couple, $1-2$ children & 21 & 13.1 & 104 & 13.3 \\
\hline Couple, $3+$ children & 10 & 6.3 & 43 & 5.5 \\
\hline Other hh w children & 9 & 6.0 & 48 & 6.1 \\
\hline Total & 158 & 100.0 & 781 & 100.0 \\
\hline
\end{tabular}

Source: Own analysis with EUROMOD and SORESI.

\subsection{MINIMUM INCOME BENEFIT-SCENARIOS: IMPACT ON INCOME DISTRIBUTION AND RISK OF POVERTY}

Depending on the scenario, the replacement of unemployment assistance by minimum income benefit leads to a reduction in household income for 81 to $95 \%$ of all $(736,000)$ household members in unemployment-assistance households. In the case of the $5 \%$ to $19 \%$ of household members where the household income is increased by the reform, a previous non-take-up of topping-up supplementary minimum income benefit should be the main reason. ${ }^{12}$

\footnotetext{
${ }^{12}$ In the reform scenarios, $100 \%$ take-up of entitled minimum income benefit is assumed (see also appendix). Numerous research studies (for example, Hernanz et al., 2004; Matsaganis et al., 2013; for Austria: Fuchs, 2009) prove that this is a simplifying assumption.
} 
The average loss of equivalised annual total household income per member in an unemployment-assistance household is 1,344 EUR in the basic scenario (S1) and increases in the capping scenario with asset check for capital income (S3) up to 2,292 EUR. Compared to the mean equivalised income of members in unemployment-assistance households of 18,264 EUR before the reform, this would imply an average income reduction of $7.4 \%$ in the basic scenario (S1) and an average income reduction of $12.5 \%$ in the capping scenario $(\mathrm{S} 3) .{ }^{13}$

In the basic scenario (S1) the number of people at risk of poverty ${ }^{14}$ is increased by 86,000 persons, with asset check for capital income (S2) by a further 6,000 , and in the capping scenario (S3) by a further 63,000 , i.e. a total increase of 155,000 persons at risk of poverty in S3. Correspondingly, the risk of poverty rate increases from $13 \%$ in the status quo to $14 \%$ in the basic scenario (S1) and to $15 \%$ in the other two scenarios (S2 and S3).

The poverty gap increases in the scenario with proxy for capital income (S2) as well as in the capping scenario (S3) from $19 \%$ to $20 \%$, while in the basic scenario (S1) the indicator remains unchanged at $19 \%$.

The Gini coefficient increases from 0.26 to 0.27 with the exception of the basic scenario (S1) (see table 7).

\section{TABLe 7}

Status quo (unemployment assistance) and simulated minimum income benefitscenarios: impact on income (inc.), income distribution and risk of poverty

\begin{tabular}{|c|c|c|c|c|c|c|}
\hline Scenario & $\begin{array}{l}\text { hh members } \\
\text { w reduced } \\
\text { inc. in \% all }\end{array}$ & $\begin{array}{c}\text { Loss per } \\
\text { capita- } \\
\text { inc./year }\end{array}$ & $\begin{array}{c}\text { People at risk } \\
\text { of poverty in } \\
1,000\end{array}$ & $\begin{array}{c}\text { At-risk- } \\
\text { of-poverty } \\
\text { rate in \% }\end{array}$ & $\begin{array}{c}\text { Poverty } \\
\text { gap in } \\
\%\end{array}$ & Gini \\
\hline Status quo & - & - & 1,137 & 13 & 19 & 0.26 \\
\hline $\begin{array}{l}\text { Basic without } \\
\text { asset check (S1) }\end{array}$ & 80.8 & $-1,344$ & $1,223(+86)$ & 14 & 19 & 0.26 \\
\hline $\begin{array}{l}\text { Basic with asset } \\
\text { check capital } \\
\text { income (S2) }\end{array}$ & 82.2 & $-1,536$ & $1,229(+92)$ & 15 & 20 & 0.27 \\
\hline $\begin{array}{l}\text { Ceiling } 1,500 \\
\text { with asset } \\
\text { check capital } \\
\text { income (S3) }\end{array}$ & 95.3 & $-2,292$ & $1,292(+155)$ & 15 & 20 & 0.27 \\
\hline
\end{tabular}

Source: Own analysis with EUROMOD/SORESI.

Results by socio-demographic characteristics are again presented only for the basic scenario without asset check (S1) since the results for the other two scenarios tend to go in a similar direction.

\footnotetext{
${ }^{13}$ Compared to the mean equivalised income of all persons in EU-SILC (uprated to 2017 with policies 2017) before the reform of EUR 26,892, this would imply an average income reduction of $5.0 \% / 8.5 \%$.

${ }^{14} 60 \%$ of median income is used as threshold for risk of poverty.
} 
The average loss of equivalized annual household income per member in an unemployment-assistance household (all: 1,344 EUR) is the highest for men (1,630 EUR), followed by women (1,283 EUR) and children (1,008 EUR). The household types with highest losses because of the reform are single persons $(1,824$ EUR) and households with at least two adults without children (1,752 EUR).

Of the 86,000 persons that are additionally at risk of poverty because of the reform, 34,000 are men (40\%), 27,000 women (31\%) and 26,000 children (30\%). Household types with the highest increase in absolute numbers are those with at least two adults without children $(+19,000)$, households with at least two adults with three and more children as well as single persons $(+18,000$ each).

A reform would increase the at-risk-of-poverty rate of the total population from 13 to $14 \%$. It would increase most for children (from $16 \%$ to $18 \%$ ). For women it would increase from 13 to $14 \%$ and for men from 12 to $13 \%$. The household types facing the highest increase in the at-risk-of-poverty rate would be single parents (from 24 to 27\%) and households with at least two adults with three and more children (from 23 to $26 \%$ ) followed by single persons (from 23 to $25 \%$ ).

\section{CONCLUDING REMARKS}

If the Hartz-IV reform were to be transferred to Austria, this would imply that after expiration of unemployment benefit, instead of unemployment assistance as a means-tested insurance benefit, the social-assistance-type minimum income benefit would be the follow-up benefit. The analysis of the direct (monetary) effects of a corresponding application of the German model is carried out using the tax-/benefit microsimulation models EUROMOD and SORESI for the policy year 2017 based on the latest EU-SILC 2015 micro-data from Statistics Austria.

First, a basic scenario (S1) corresponding to the regulations for minimum income benefit in the nine federal states for the year 2017 is simulated without an asset check. However, for the entitlement to minimum income benefit, own assets are also relevant. As there is no relevant information in the EU-SILC data, a proxy is applied in the second scenario (S2): exclusion from entitlement to minimum income benefit where there is capital income, which, assuming a net interest rate of $1 \%$, exceeds the stipulated amounts of exemption. Following the current political discussions and developments, a third scenario (S3) with a capping of the monthly household income of households receiving minimum income benefit at EUR 1,500 is simulated for all federal states (including the proxy for asset check).

According to the EU-SILC data there are 277,000 households (7.3\% of all households in EU-SILC) receiving unemployment assistance (for at least one month in the reporting year) with 736,000 household members. The total expenditure (uprated to 2017) for unemployment assistance amounts to 1,454 million EUR ( $0.42 \%$ of GDP 2016 and $1.45 \%$ of total social expenditure 2015$)$. Out of the unemployment-assistance households, 56,000 households receive in addition 
benefits aimed at preventing social exclusion of EUR 338 million. In sum, both benefits amount to 1,792 million EUR ( $0.51 \%$ of GDP 2016 and $1.79 \%$ of total social expenditure 2015).

The basic simulation scenario for minimum income benefit (S1) with still 158,000 receiving households leads to a lower expenditure of 673 million EUR ( $-0.19 \%$ of GDP 2016 and $-0.63 \%$ of total social expenditure 2015) in comparison to the status quo. The reduced expenditure increases by a further 111 million EUR (total -784 million EUR or $-0.22 \%$ of GDP 2016 and $-0.78 \%$ of total social expenditure 2015 ) with the use of the proxy for capital income (S2; still 131,000 receiving households). Significant additional reductions result from the capping scenario (S3). In this case the benefits aimed at preventing social exclusion from the SILC-data are also affected by cuts: compared to the basic scenario with asset check, there is additional reduced expenditure of 318 million EUR (total -1,102 million EUR or $-0.32 \%$ of GDP 2016 and $-1.10 \%$ of total social expenditure 2015), with 93,000 households receiving simulated minimum income benefit and 42,000 households receiving benefits preventing social exclusion from the SILC-data. However, in all scenarios, the revenue from income tax is reduced by about 30 million EUR ( $0.01 \%$ of GDP 2016) due to the abolishment of unemployment assistance.

Concerning the distribution of income and the risk of poverty, the replacement of unemployment assistance by minimum income benefit, depending on the scenario, leads to a reduction in household income for 81 to $95 \%$ of all household members in unemployment-assistance households. The average loss of equivalized annual total household income per household member in the basic scenario (S1) is around 1,300 EUR and increases with the capping scenario with asset check (S3) to around 2,300 EUR. Compared to the mean equivalised annual income of members in unemployment-assistance households of 18,300 EUR before the reform, this would imply an average income reduction of $7.4 \%$ in the basic scenario (S1) and an average income reduction of $12.5 \%$ in the capping scenario (S3). ${ }^{15}$

The number of people at risk of poverty increases in the basic scenario (S1) by 86,000 persons, with asset check (S2) by a further 6,000 and in the capping scenario with asset check (S3) by a further 63,000 , i.e. a total increase of 155,000 persons at risk of poverty in S3. Correspondingly, the at-risk-of-poverty rate increases from $13 \%$ in the status quo to $14 \%$ in the basic scenario (S1) and to $15 \%$ in the other two scenarios. The Gini coefficient increases from 0.26 to 0.27 with the exception of the basic scenario (S1).

In sum, it can be concluded that the replacement of unemployment assistance by minimum income benefit on the one hand would lead to considerable reductions

\footnotetext{
${ }^{15}$ Compared to the mean equivalised income of all persons in EU-SILC (uprated to 2017 with policies 2017) before the reform of EUR 26,900, this would imply an average income reduction of $5.0 \% / 8.5 \%$.
} 
in social expenditure. As there is more a strategic than a concrete interest in this hypothetical reform in Austria, it is not known how the potential resulting spending reduction would be allocated by the Federal Government and/or the governments of the federal states. On the other hand the reform would cause significant changes in income distribution and increases in risk of poverty. However, this purely monetary analysis fails to estimate the potential additional social costs resulting from an increase in poverty. Such an investigation is outside the scope of EUROMOD and SORESI.

Based on experiences in Germany (cf. e.g. Bäcker, Bosch and Weinkopf, 2011; Baethge-Kinsky, Bartelheimer and Wagner, 2010; Bräuninger, Michaelis and Sode, 2013; Brussig and Knuth, 2011; Dörre et al., 2013; Fitzenberger, 2009; Hassel and Schiller, 2010; Jacobi and Kluve, 2006; Klinger, Rothe and Weber, 2013; Launov and Wälde, 2013; Schneider, 2006) it is difficult to judge the potential behavioural and labour-market-related outcomes of such a reform. Some argue that in Germany it increased the efficiency of the welfare system by shortening unemployment durations and that it contributes to the reduction of unemployment by increasing incentives for taking up employment especially for the longterm unemployed.

However, others are of the opinion that measures for labour market support, personal services and job placement (Hartz I-III) were more important for the labour market integration of clients than the concrete benefit design (Hartz IV). Furthermore it is said that the "positive" employment effects of Hartz IV result more from a deterrent than from a supportive effect. Particularly, the job-seeking activities tends to intensify in particular just before the insurance-related unemployment benefit I expires.

In addition, the change to the new benefit (unemployment benefit II) was accompanied by a primary orientation towards a quick, but often not lasting, reduction of need for assistance. Also, the limits of activation became obvious: transition into unsubsidised employment is rare due to labour market shortage, especially for unemployed persons with multiple restrictions who are difficult to place. Furthermore, unemployment benefit II turned into an instrument of a means-tested wage top-up, which subsidises low wages.

In sum, experiences with the German Hartz-IV reform are mixed but also need further research for a final evaluation.

\section{Disclosure statement}

No potential conflict of interest was reported by the authors. 
MINIMUM INCOME BENEFIT REGULATIONS OF THE FEDERAL STATES (OVERVIEW)

A person whose means of subsistence plus housing needs are not (sufficiently) secured by his/her own resources (income, assets) or prior social benefits (e.g. unemployment benefit, maintenance payments) is legally entitled to minimum income benefit. The right to permanent residence in Austria is another fundamental eligibility requirement. ${ }^{16}$

Minimum income benefit is provided by means of flat-rate cash benefits to secure subsistence costs and housing needs. The initial value for single persons and single parents is EUR 844.46 in 2017. The agreement between the federal government and the federal states stipulates that the minimum standards for additional persons are certain percentages of this base:

$-75 \%$ for adult persons living with other adult persons in a common household;

$-50 \%$ for the third and subsequent entitled adult persons;

$-18 \%$ for the first three minor children;

$-15 \%$ for the fourth child and subsequent children.

The minimum standards are basically granted twelve times a year and include a basic amount of 25\% for housing needs (in 2017 EUR 211.12 for single persons and single-parent households). If the appropriate housing needs cannnot be fully covered with these basic amounts, the federal states may provide additional benefits.

Based on the agreement, all federal states have passed minimum income decrees. The implementation shows a number of federal state-specific features.

\section{Higher minimum standards}

In Upper Austria, higher minimum standards apply than those laid down in the agreement between the federal government and the federal states. The included basic amount for housing is $18 \%$ (instead of the usual $25 \%$ ).

\section{Special payments}

In Vienna, persons who have reached the regular retirement age or who are classified as incapacitated also receive higher benefits by special payments. There are also special payments in Tyrol and - limited to minors - in Salzburg and Styria. In these three federal states, the special payments depend on the length of the minimum income receiving period (entitlement from three months receiving duration onwards). ${ }^{17}$

\footnotetext{
${ }^{16}$ It is assumed that there is no reason for exclusion from minimum income benefit with regard to the right to permanent residence in case of entitlement to the insurance benefit unemployment assistance (no corresponding information is available in EU-SILC data).

${ }^{17}$ For these federal states, given that other entitlement conditions are provided, special payments were simulated (aliquot) for those households, which show an unemployment assistance receiving period of three or more months in SILC. However, in the SILC data only the unemployment assistance months from the reporting year are shown but not any receiving months already dating from the previous year(s).
} 


\section{Children's standard rates}

With the exception of Carinthia, all federal states grant higher minimum standards for minor children than is provided for in the federal government/federal states agreement:

- Burgenland for all children $19.2 \%$;

- Lower Austria for all children 23\%;

- Upper Austria (based on the higher initial value) for the first three children $23 \%$, for all other $20 \%$;

- Salzburg for all children $21 \%$;

- Styria for the first four children $19 \%$ and for all other $23 \%$;

- Tyrol and Vorarlberg (in each case based on subsistence costs without housing costs) for all children $33 \%$ and $29 \%$;

- Vienna for all children $27 \%$.

\section{Housing need}

Tyrol and Vorarlberg assume $75 \%$ of the initial value for means of subsistence and provide a more generous regulation for the housing need than the usual $25 \%$ share of basic housing need since the actual housing costs are covered to certain maximum limits. In Vienna and Styria, there is a legal right to additional benefits for housing. Salzburg also provides for additional benefits, without legal entitlement, and takes into account different regional housing costs, just like Styria. In Burgenland, in Carinthia, as well as in Lower- and Upper Austria, additional benefits for the purpose of covering housing needs (beyond the basic amount for housing) are on principle not granted. Differences in the minimum income benefit regulations also concern the extent to which general housing allowances (outside minimum income benefit) are taken into account in the means-test (only included in the means-test for housing need or also in the means-test for means of subsistence, etc.) and whether the basic amount for housing is reduced if housing costs are lower (cf. Pratscher, 2016).

\section{Overview on differences between federal states}

Differences in the detailed regulations between the federal states (S: minimum income benefit laws and decrees; Armutskonferenz, 2012; Mundt/Amann, 2015) can be discerned mainly regarding the following issues:

- types and amount of standard rates; with/without basic amount for housing; with/without special payments;

- potential reduction of the basic amount for housing costs where there are no or lower housing costs;

- additional benefits for housing needs provided by the federal states;

- general housing allowances (outside minimum income benefit) only included in the means-test for housing needs or also in the means-test for means of subsistence, etc.;

- (non-)including of other incomes in the means-test;

- amounts of exemptions for income from work;

- payment obligations (e.g. maintenance payments) to be taken into account;

- accessibility of heating cost allowance for minimum income benefit recipients. 
As far as enabled by the information available in the EU-SILC data, the relevant regulations of the individual federal states were modeled for the simulation of minimum income benefit $1: 1$.

\section{(ADDITIONAL) CORRECTIONS MADE IN THE SILC DATA FOR THE SIMULATION OF MINIMUM INCOME BENEFIT}

In addition to corrections of income data not or only partly counting in the meanstest for minimum income benefit, etc. (see above), for the unemployment assistance months the following corrections were made in the SILC-data:

- unemployment assistance: set to 0 because minimum income benefit is simulated instead;

- unemployment benefit of unemployment assistance recipients: for unemployment assistance months set to 0 since simultaneous receipt with unemployment assistance (apart from overlaps) can be excluded;

- further unemployment allowances (transitional allowance, education allowances, etc.), expense allowance (e.g. for public employment service course attendance) of unemployment assistance recipients: set to 0 since as a rule, further unemployment benefits should be drawn up before or after unemployment assistance. Expense allowances are also received in addition to unemployment assistance. However, if a corresponding expense allowance is also paid out to minimum income benefit recipients (and does not count as income in the means-test), it is a zero-sum game;

- benefits preventing social exclusion: remain basically unchanged within the simulation of minimum income benefit for unemployment assistance months and are taken into account in the means test 1:1; these benefits are not affected by the proxy for the asset check since it is assumed that in reality a basic asset check has already been completed and that it continues to exist unchanged; as regards simulation Scenario 3 (capping), a correction of the simulated minimum income benefit with the EUR 1,500 exceeding amount of the total household income is first carried out, in case the simulated minimum income benefit is reduced to 0 a corresponding correction of the benefit against social exclusion from the SILC-data is also made since the capping was newly introduced;

- employment and self-employed income of unemployment assistance recipients within the unemployment assistance receiving period (entitlement to unemployment assistance is possible up to the marginal earnings threshold): the respective amounts of exemption for earnings within the minimum income benefit regulations were applied where there is unemployment assistance receipt for at least six months;

A basic problem related to the income variables in the SILC-data is that income that is not received in all twelve calendar months is difficult to allocate to the individual calendar months. Apart from alternatively simulated minimum income benefit (on the basis of the number of unemployment assistance months) as well 
as other specifications for employment and self-employment income, ${ }^{18}$ basically all income from the data is included in the calculations as a year-twelfth.

\section{ANALYSIS OF COSTS AND RECIPIENTS (-HOUSEHOLDS)}

As far as possible, the adjusted income data for the simulation of minimum income benefit apply for one (unemployment assistance) month each. Simulated minimum income benefit (per month) is multiplied by the number of months of unemployment assistance receipt. A comparison of original unemployment assistance and alternatively simulated minimum income benefit with regard to expenditure and recipients(-households) is carried out.

The evaluations are carried out exclusively on the basis of unemployment-assistance households for the receiving months according to EU-SILC. Unweighted, the persons/households with unemployment assistance relevant for the analysis are as follows:

- households with unemployment assistance recipients: 361;

- unemployment assistance recipients: 381 ;

- members in unemployment-assistance households: 895.

\section{ANALYSIS OF IMPACT ON INCOME DISTRIBUTION AND RISK OF POVERTY}

Apart from unemployment assistance, simulated minimum income benefit and benefits against social exclusion (see above), all incomes are also included in their original form in the reform scenarios. That is, the further income corrections for the simulation of minimum income benefit (income not or only partly to be considered in the means-test, amounts of exemption for earnings, etc.) are reversed (the corresponding EU-SILC original data is used) as these incomes actually were accrued by the respective households.

The analyses are based on all persons in the EU-SILC-data on a yearly basis. For the calculations of the risk of poverty, the at-risk-of-poverty threshold from the original data is left unchanged (= fixed poverty line).

Unweighted, the total number of persons/households in EU-SILC 2015 is as follows:

- households: 6,045;

- persons: 13,213 .

\section{POTENTIAL NON-TAKE-UP OF MINIMUM INCOME BENEFIT}

The simulation results are influenced to a certain extent by current (before the potential reform) and future (following the potential reform) non-take-up of minimum income benefit:

\footnotetext{
${ }^{18}$ Estimation of the receiving period for income from work on the basis of the following variables: employment status January-December, annual amount, number of receiving months for income from work, number of receiving months for unemployment assistance in the SILC data.
} 
- Current non-take-up of minimum income benefit: persons with unemployment assistance below the standard rates of minimum income benefit that would be entitled to a supplement: with the relatively low minimum income benefit amounts they are entitled to, it can be assumed that some unemployment-assistance households will abstain from application for supplementary minimum income benefit. However, with the abolition of unemployment assistance, the gap in income will be greater and thus the application for minimum income benefit is more likely. Since there are also households with income gains in all simulated minimum income benefit scenarios, it can be assumed that of the 277,000 unemployment-assistance households there are up to $20 \%$ of households that are entitled to supplementary minimum income benefit but do not apply for it.

- Potential future non-take-up of minimum income benefit: especially in the case of households (or persons) that are only entitled to a relatively low supplementary minimum income benefit after the abolition of the unemployment assistance (due to other household income), it can be assumed that, in reality, there will be some non-take-up of minimum income benefit. 


\section{REFERENCES}

1. AK (Kammer für Arbeiter und Angestellte), 2017. Sozialleistungen im Überblick. Lexikon der Ansprüche und Leistungen. Wien.

2. AK Wien (Kammer für Arbeiter und Angestellte Wien Hofbauer), 2016. Hartz-Reformen in Deutschland und ihre Folgen. Available at: <https://media. arbeiterkammer.at/wien/PDF/varueckblicke/AK_Hartz_Reformen_Folgenund-Alternativen_10-2016.pdf>.

3. Armutskonferenz, 2012. Monitoring „Bedarfsorientierte Mindestsicherung “. Analyse und Vergleich der Länderbestimmungen zur Bedarfsorientierten Mindestsicherung 2011. Wien. Available at: <http://www.sozialarbeit.at/files/ matrix_bms_monitoring_final.pdf $>$.

4. Bäcker, G., Bosch G. and Weinkopf, C., 2011. Vorschläge zur künftigen Arbeitsmarktpolitik: integrativ - investiv - in-novativ. Essen: Universi-tät Duisburg Essen. Available at: <http://www.sozialpolitik-aktuell.de/tl_files/sozialpolitik-aktuell/_Politikfelder/Arbeitsmarkt/Dokumente/IAQ_Gutachten_ Auszug_Bewertung_Hartz_Gesetze.pdf $>$.

5. Baethge-Kinsky V., Bartelheimer P. and Wagner, A., 2010. Die "Hartz-Gesetze", ihre wissenschaftliche Evaluation und deren Verarbeitung. Schlussbericht des Transferprojekts "Monitor Arbeitsmarktpolitik". Göttingen; Berlin: Sozio-logisches Forschungsinstitut Göttingen an der Georg-August-Universität gefördert von der Hans-Böckler-Stiftung und der Otto-Brenner-Stiftung.

6. Bock-Schappelwein J. [et al.], 2014. Aktive und passive Arbeitsmarktpolitik in Österreich und Deutschland: Aufkommen und Verwendung der Mittel im Vergleich. Wien: WIFO. Available at: <http://www.forschungsnetzwerk.at/downloadpub/AMS_akt_pass_AT_DE_13032014-ENDBERICHT_und_Deckblatt.pdf $>$.

7. Bräuninger, M., Michaelis, J. and Sode, M., 2013. 10 Jahre Hartz-Reformen. Studie im Auftrag der Initiative Neue Soziale Marktwirtschaft GmbH (INSM). HWWI Policy Paper, Nr. 73. Available at: <http://www.hwwi.org/uploads/ tx_wilpubdb/HWWI_Policy_Paper_73.pdf $>$.

8. Brussig, M. and Knuth, M., 2011. Die Zukunft der Grundsicherung - Individualisieren, konzentrieren, intensivieren. Expertise im Auftrag der Abteilung Wirtschafts- und Sozialpolitik der Friedrich-Ebert-Stiftung. WISO Diskurs, No. 12. Available at: <http://library.fes.de/pdf-files/wiso/08713.pdf >.

9. Dörre, K. [et al.], 2013. Bewährungsproben für die Unterschicht? Soziale Folgen aktivierender Arbeitsmarktpolitik. International Labour Studies - Internationale Arbeitsstudien, Band 3. Frankfurt am Main; New York: Campus.

10. Fitzenberger, B., 2009. Nach der Reform ist vor der Reform? Eine arbeitsökonomische Analyse ausgewählter As-pekte der Hartz-Reformen. Freiburg: AlbertLudwigs-Universität Freiburg.

11. Fuchs M., 2009. Nicht-Inanspruchnahme von Sozialleistungen am Beispiel der Sozialhilfe in: N. Dimmel, K. Heitzmann and M. Schenk, eds. Handbuch Armut in Österreich. Innsbruck: Studienverlag Innsbruck, pp. 290-301.

12. Fuchs, M. and Gasior, K., 2014. Social Reform Microsimulation (SORESI). A web-based citizens' tool to model the social impact of taxes and benefits in Aus- 
tria. European Centre for Social Welfare Policy and Research Policy Brief, April. Available at: <http://www.euro.centre.org/data/1396346607_61195.pdf>.

13. Hassel, A. and Schiller, Ch., 2010. Die politische Dynamik von Arbeitsmarktreformen in Deutschland am Beispiel der Hartz IV-Reform. Abschlussbericht: Hans-Böckler-Stiftung.

14. Hernanz, V., Malherbert F. and Pellizzari, M., 2004. Take-Up of Welfare Benefits in OECD Countries: A Review of the Evidence. OECD Social, Employment and Migration Working Papers, No. 17. Available at: $<\mathrm{http} / /$ www.oecd. org/social/soc/30901173.pdf $>$.

15. Jacobi, L. and Kluve, J., 2006. Before and After the Hartz Reforms: The Performance of Active Labour Market Policy in Germany. IZA Discussion Papers, No 2100. Available at: <http://ftp.iza.org/dp2100.pdf>.

16. Klinger, S., Rothe, T. and Weber, E., 2013. Makroökonomische Perspektive auf die Hartz-Reformen: Die Vorteile überwiegen. IAB-Kurzbericht, No. 11. Available at: $<\mathrm{http}: / /$ doku.iab.de/kurzber/2013/kb1113.pdf $>$.

17. Lamei N. [et al.], 2017. Lebensbedingungen, Armut und Einkommen in Österreich in: Sozialbericht, Sozialpolitische Entwicklungen und Maßnahmen 2015-2016. Wien: Paul Gerin \& Co, pp. 179-226. Available at: <https://broschuerenservice.sozialministerium.at/Home/Download?publicationId=372>.

18. Launov, A. and Wälde, K., 2013. Hartz IV ist tot - Es leben die Hartz-Reformen! Gutenberg School of Management and Economics Discussion Paper Series, No. 1308. Available at: <http://wiwi.uni-mainz.de/Dateien/DP_1308.pdf $>$.

19. Matsaganis, M., Ozdemir E. and Ward, T., 2014. The Coverage Rate of Social Benefits, European Commission Social Situation Observatory. Research Note, No. 9. Available at: <http://ec.europa.eu/social/BlobServlet?docId=11523\&la ngId $=$ en $>$.

20. Mundt, A. and Amann, W., 2015. Bestandsaufnahme von monetären Leistungen für untere Einkommensgruppen zur Deckung des Wohnbedarfs, Studie im Auftrag des Sozialministeriums. Wien: Institut für Immobilien, Bauen und Wohnen.

21. Pratscher, K., 2016. Bedarfsorientierte Mindestsicherung der Bundesländer im Jahr 2015. Statische Nachrichten, No. 11, pp. 846-858.

22. Schmidt C. M., 2016. Zukunftsfähigkeit von Wirtschaft und Gesellschaft: der Arbeitsmarkt steht im Mittelpunkt. Available at: <https://news.wko.at/news/ oesterreich/schmidt-arbeitsmarkt-wkoe-wien-04apr2016.pdf>.

23. Schneider, H., 2006. Erste Erfahrungen mit Hartz IV - Ordnungspolitische Evaluation in: Strategien gegen Arbeitslosigkeit und Armut - Was kommt nach Hartz IV? pp. 5-7. Available at: <http://www.kas.de/wf/doc/kas_7921-544-130.pdf?060403095543=page $>$.

24. Statistik Austria, 2016. Standard-Dokumentation Metainformationen (Definitionen, Erläuterungen, Methoden, Qualität) zu EU-SILC 2015. Wien: Statistik Austria.

25. Sutherland, H. and Figari, F., 2013. EUROMOD: the European Union taxbenefit microsimulation model. International Journal of Microsimulation, 1(6), pp. 4-26. 